\title{
TOXICITY POTENTIAL OF PARTICULATES IN THE AIRSHED OF HAULAGE VEHICLE PARK
}

\author{
FAKINLE B.S. ${ }^{1}$ \\ SONIBARE J.A. ${ }^{1, *}$ \\ AKEREDOLU F.A. ${ }^{1}$ \\ OKEDERE O.B. ${ }^{2}$ \\ JIMODA L.A. ${ }^{3}$
}

\author{
${ }^{1}$ Environmental Engineering Research Laboratory, \\ Department of Chemical Engineering, \\ Obafemi Awolowo University, Ile-Ife, Nigeria \\ ${ }^{2}$ College of Science, Engineering and Technology, \\ Osun state University, Osogbo, Nigeria \\ ${ }^{3}$ Department of Chemical Engineering, \\ Ladoke Akintola University of Technology, Ogbomoso, Nigeria
}

Received: $12 / 09 / 12$

Accepted: 15/04/13 *to whom all correspondence should be addressed: e-mail: asonibar@oauife.edu.ng; asonibar@yahoo.com

\begin{abstract}
This study examined the toxicity potential of total suspended particulate in the airshed of a haulage vehicle park located in a major highway connecting Lagos, the commercial centre of Nigeria to its other parts. It has an approximate area of $0.6 \mathrm{~km}^{2}$. Ambient air total suspended particulates (TSP) were monitored at five different sub- parks using the GT331 particulate monitor. A control sampling point was also set at about a kilometer southward of the sub-parks. The average measured particulate concentrations within the park ranged between 197.07 and $653.28 \mu \mathrm{g} \mathrm{m}^{-3}$ with an average of $334.5 \mathrm{\mu g} \mathrm{m}^{-3}$ but at the control point, it was between 18.5 and $46.6 \mu \mathrm{g} \mathrm{m}^{-3}$ with an average of $36.23 \mathrm{\mu g} \mathrm{m}^{-3}$. An assessment of toxicity potential of these particulates shows unhealthy air conditions at the haulage park. It was between 0.58 and 6.00 at the park's sampling points but ranged between 0.11 and 0.33 at the control location. This study establishes that haulage vehicles may contribute significantly to its host airshed degraded air quality thus calls for appropriate regulatory measure to protect commuters plying the major highway around the park.
\end{abstract}

KEYWORDS: Total suspended particulate, haulage Vehicle Park, toxicity potential, and diesel.

\section{INTRODUCTION}

The collapse of rail transportation over the years in Nigeria has made the use of diesel engine powered haulage vehicles a necessity for movement of heavy goods within the country. A consequence of this is the emergence of several haulage vehicle parks along its major highways. One of such parks is located at Ogere in Ogun State (Plate 1) along the highly busy Lagos - Ibadan inter-city express way which is about $50 \mathrm{~km}$ from Lagos, the commercial capital of Nigeria. Lagos has several industrial estates and it is even presently proposing four additional new ones. Due to the production levels of the process and chemical industries operating in these industrial estates, there is a need for continuous supply of raw materials and evacuation of finished products, thus calling for haulage vehicles. However, the shortage of land is preventing these industries from having designated vehicle parks around their immediate environment in Lagos and this has necessitated their location outside the city. From Lagos traffic regulation, vehicles are not allowed to be parked on the roadside and the emergence of this haulage park could be as a result of continuous eviction of haulage vehicles off the Lagos roadsides. The number of haulage vehicles count at this park (Ogere's park) is approximately about 1000 trailers per day. All these heavy duty vehicles run on diesel fuel. Though, diesel engines are attractive in terms of performance, they are still one of the major sources of particulate emissions especially in urban areas (Collings and Graskow, 2000; Xing et al., 2012). 


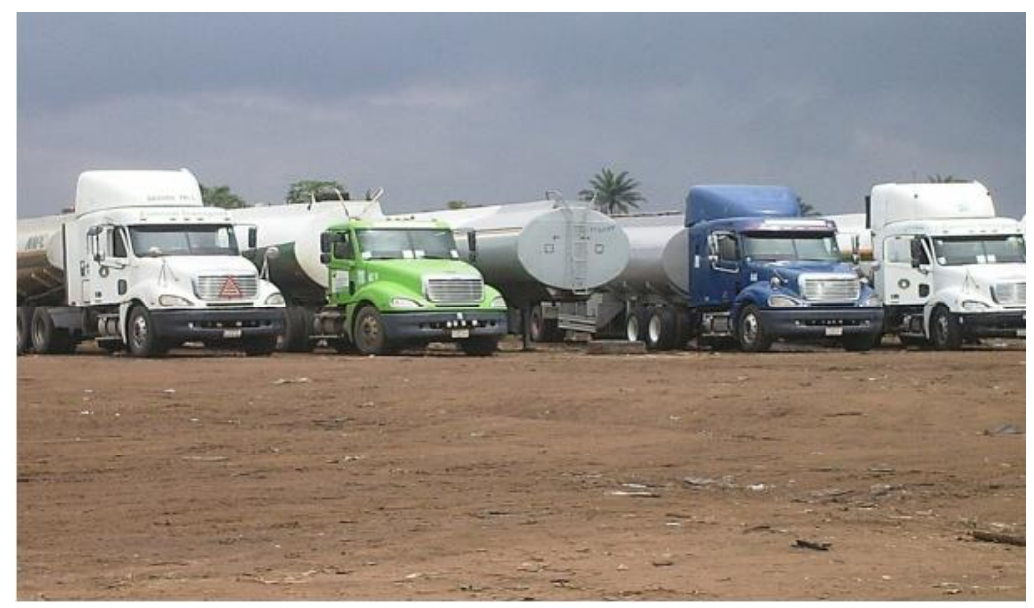

Plate 1. Typical Scene in the Environs of the Studied Haulage Park, Ogere, Nigeria

Particulate matter (PM) emissions from energy production systems have been of concern due to their impacts on human health and the environment (Fridell et al., 2008; Ramanathan and Carmichael, 2008). The health hazards of diesel particulate matters (DPM) are well known and a concentration of about $200 \mu \mathrm{g} \mathrm{m}^{-3}$ at short exposure period of $2 \mathrm{hrs}$ can lead to airway inflammatory response (Nigthtingale et al., 2000; Behndig et al., 2006). Most of the DPM consists of elemental carbon core of 0.01- $0.08 \mu \mathrm{m}$ in diameter (Gan et al., 2010). As a result of these health concerns, several authorities have set exposure standards or guidelines for DPM. In 1995, the American Conference of Governmental Industrial Hygienists (ACGIH) proposed an 8-hr Threshold Limit Value (8-hr TLV) of $0.15 \mathrm{mg} \mathrm{m}^{-3}$ which was reduced to $0.05 \mathrm{mg} \mathrm{m}^{-3}$ in 1998. The German occupational exposure limit set by the Bundesministerum fur Arbiet (BMA) is $0.1 \mathrm{mg} \mathrm{m}^{-3}$ (based on elemental carbon content) while the US Mine and Safety Health Administration (MSHA) has set a target exposure limit (8-hr TLV) of $0.16 \mathrm{mg} \mathrm{m}^{-3}$ (based on total carbon). Other sources of particulate in haulage vehicle park include dust re-suspension (Thorpe, 2007), tyre wears (Warner, 2002; Andreas et al., 2006) and brake wears (Hulskotte, et al., 2007) due to vehicle movements in and out of such park.

The studies on toxicity potential of DPM have predicated upon growing human health concern about PM inhalation (Pope, 2000; Oberdorster and Utell, 2002; Nel, 2005; Abbas et al., 2007; Otto et al., 2007; Sacks et al., 2010). Particulate matter whether by intrinsic or extrinsic toxicities have been known to pose severe health hazards due to the hypothetical mechanism of the adverse effects of particulate through metal-generated free radicals (Guinée and Heijungs, 1993; Gilmour, 1996; Lu et al., 2008). Owoade et al. (2009) reported that the calculated toxicity potential value that exceeds unity using the threshold limits is worrisome.

Quite a number of traffic pollution studies have been carried out in Nigeria. However, most of these studies have focused on intra-city roads where different vehicle types are always on the move. In this study, total suspended particulate loading in the airshed of an unregulated haulage vehicle park at Ogere, Ogun State, Nigeria was monitored. Due to human activities at the study site it was considered needful to evaluate the toxicity potential of particulate at the various sections of the studied region.

\section{MEASUREMENT METHOD AND TOXICITY POTENTIAL CALCULATION Study area description.}

The study area was the haulage vehicle park located in Ogere, Ogun State, Nigeria. Its geographical coordinates are $6^{\circ} 56^{\prime} 0$ " North and $3^{\circ} 38^{\prime} 0$ " East. The park is between kilometers 56 and 59 from Lagos along Lagos-lbadan express way in Nigeria which is a dual carriage way with a dimension of $3 \times 0.2 \mathrm{~km}$. However the studied area starts on kilometer 57 covering five different locations while the control point was located on kilometer 55 from Lagos (Figure1). This control point was chosen to allow for comparison with an airshed along the same dual carriage way but outside the influence of the haulage vehicles activities as obtained in the park. The presence of this park has boosted commercial activity in the area and this has resulted in its high population density. The average 
number of vehicles (mostly diesel fueled haulage vehicles) within the park is usually about 1000 count/day excluding those plying the highway.

Sampling point $\mathrm{S} 1$ is on kilometer 57 and in between the two lanes of the highway to capture the contribution of vehicles passing through the park but coming from or going to Lagos. This point is directly exposed to vehicular movement. Sampling Point S2, defined as the midpoint of the study region is in front of a filling station at kilometer 57.5 from Lagos. Sampling Point S3 is at the end of the region on kilometer 58. Commercial and domestic activities at this point are relatively less compare to the other points. Sampling Point S4 is at another oil filling station at kilometer 57 which is within the trailer park and a motel situated within the study area, sampling was done at the left side of the filling station. Sampling Point S5 is in a sub-park within the park and also at kilometer 57 . This park is one of the sub-parks for trucks in the study area. The control point was chosen as earlier indicated and it is located about a kilometer to the park just off the highway around kilometer 55 to Lagos (Figure 1).

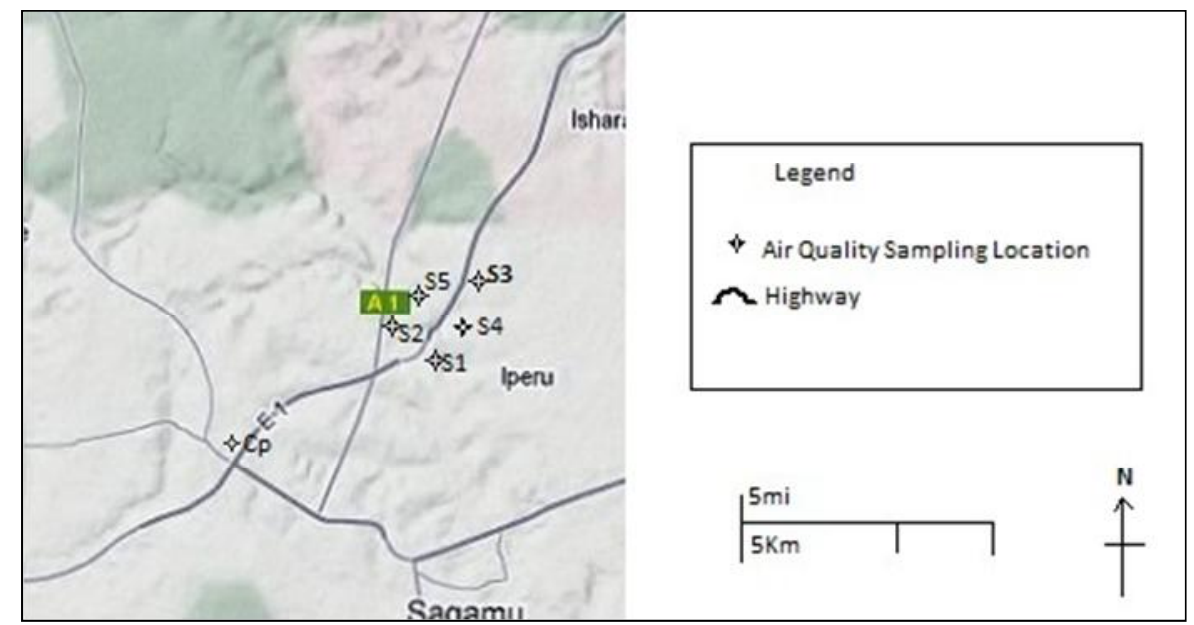

Figure 1. The Studied Area in Ogere, Ogun State, Nigeria (Google map)

\section{Sampling for TSP}

Total suspended particulates were measured at five different locations designated within the park and at the control point. The Met-One air particulate mass monitor (Model GT-331) was used to measure the ambient TSP concentration both at the park and at the control site during the study. The device is a handheld, battery operated and completely portable unit measuring five ranges of particulates: $\mathrm{PM}_{1}, \mathrm{PM}_{2.5}, \mathrm{PM}_{7}, \mathrm{PM}_{10}$ and TSP with a concentration range of $0-1 \mathrm{mg} \mathrm{m}$ (and resolution of $0.1 \mathrm{\mu g} \mathrm{m}^{-3}$ ). The monitor employs light scattering principle to size individual particles that passes through the laser optical system (no correction factor is required). Information from the manufacturer indicates that during factory calibration of the GT-331 monitor, its mass concentration reading has been checked against a Beta Attenuation Monitor (BAM) which is a reference standard method of measuring mass concentration - thus no correction of the output concentrations is needed (Met One Instruments, 2001). Its LCD display allows a real time viewing TSP. The sampler has a sampling cycle of 5 minutes. During the 8-hrs sampling period at the designated point, the particulate monitor was positioned at a sufficient height above the ground level to prevent measurement of fugitive dust mobilized by tides. With the exception of the control site the visible sources of pollutants were the haulage vehicles at the various sampling points. Measurement was carried out at each sampling location for 3 different days consecutively. The 24-hr averaging period extrapolated concentrations of the measured TSP were computed using an atmospheric stability formula (Bashar et al., 2009) given in Equation (1) as:

$\mathrm{C}_{0}=\mathrm{C}_{1} \mathrm{XF}$

where $\mathrm{C}_{0}=$ the concentration at the averaging period $\mathrm{t}_{0}$

$\mathrm{C}_{1}=$ the concentration at the averaging period $\mathrm{t}_{1}$

$F=$ factor to convert from the averaging period $t_{1}$ to the averaging period $t_{0}=\left(\frac{t_{1}}{t_{0}}\right)^{n}$

$\mathrm{n}=0.28$, the stability dependent exponent 


\section{Toxicity Potential}

Toxicity potential, expressed as the ratio of measured ambient PM concentration to the statutory limit of ambient concentration (Sonibare et al., 2005) is useful in assessing the deleterious effects of the haulage park emissions on human health. It was computed using Eqn (2) taking into consideration the ambient air quality standards of TSP by the Federal Ministry of Environment (FMENV), World Bank (WB) and that of the World Health Organization (WHO) as reported in FEPA (1991) World Bank (1998) and WHO (1979) respectively.

Toxicity Potential $=\frac{\mathrm{M}_{\mathrm{TSP}}}{\mathrm{S}_{\mathrm{TSP}}}$

where: $\mathrm{M}_{\mathrm{TSP}}$ is the measured TSP and $\mathrm{S}_{\mathrm{TSP}}$ is the statutory limit set for TSP.

\section{RESULTS AND DISCUSSION}

Summarized in Table 1 are the 8-hr averaging period measured TSP concentrations at the various sampling points. The concentrations ranged between 197.07 and $653.28 \mathrm{\mu g} \mathrm{m}^{-3}$ with an average of $334.52 \mathrm{mg} \mathrm{m}^{-3}$ but at the control location it was $36.23 \mathrm{\mu g} \mathrm{m}^{-3}$. When extrapolated to $24-\mathrm{hr}$ averaging period concentrations (Table 2), the measured TSP became $145.53-480.29 \mathrm{\mu g} \mathrm{m}^{-3}$ with an average of $245.94 \mathrm{\mu g} \mathrm{m}^{-3}$ while at the control it was $26.64 \mathrm{\mu g} \mathrm{m}^{-3}$. The mean minimum and maximum TSP concentrations were at S4 (within a sub-park on kilometer 57 ) and S1 (in between the dual carriage way also on kilometer 57 ) respectively which could be attributed to the nature of activities associated with these sampling locations.

Table 1. Measured Total Suspended Particulates during the Study

\begin{tabular}{ccccc}
\hline $\begin{array}{c}\text { Sampling } \\
\text { Location }\end{array}$ & $\begin{array}{c}\text { Day 1 } \\
\left(\mu \mathrm{g} \mathrm{m}^{-3}\right)\end{array}$ & $\begin{array}{c}\text { Day 2 } \\
\left(\mu \mathrm{g} \mathrm{m}^{-3}\right)\end{array}$ & $\begin{array}{c}\text { Day 3 } \\
\left(\mu \mathrm{g} \mathrm{m}^{-3}\right)\end{array}$ & $\begin{array}{c}\text { Average } \\
\left(\mu \mathrm{g} \mathrm{m}^{-3}\right)\end{array}$ \\
\hline S1 & 696.47 & 509.76 & 753.61 & 653.28 \\
\hline S2 & 298.52 & 515.78 & 370.1 & 394.8 \\
\hline S3 & 279.77 & 200.66 & 208.07 & 229.5 \\
\hline S4 & 168.85 & 251.42 & 170.94 & 197.07 \\
\hline S5 & 242.77 & 179.26 & 171.82 & 197.95 \\
\hline Cp & 18.5 & 43.6 & 46.6 & 36.23 \\
\hline
\end{tabular}

Table 2. Extrapolated 24-hr Averaging Period Particulates from the Measured Levels

\begin{tabular}{ccccc}
\hline $\begin{array}{c}\text { Sampling } \\
\text { Location }\end{array}$ & $\begin{array}{c}\text { Day 1 } \\
\left(\mu \mathrm{g} \mathrm{m}^{-3}\right)\end{array}$ & $\begin{array}{c}\text { Day 2 } \\
\left(\mu \mathrm{g} \mathrm{m}^{-3}\right)\end{array}$ & $\begin{array}{c}\text { Day 3 } \\
\left(\mu \mathrm{g} \mathrm{m}^{-3}\right)\end{array}$ & $\begin{array}{c}\text { Average } \\
\left(\mu \mathrm{g} \mathrm{m}^{-3}\right)\end{array}$ \\
\hline S1 & 512.05 & 374.78 & 554.05 & 480.29 \\
\hline S2 & 219.47 & 379.20 & 272.10 & 290.26 \\
\hline S3 & 205.69 & 147.53 & 152.97 & 168.73 \\
\hline S4 & 124.14 & 184.84 & 125.68 & 144.89 \\
\hline S5 & 178.48 & 131.79 & 126.32 & 145.53 \\
\hline Cp & 13.60 & 32.05 & 34.26 & 26.64 \\
\hline
\end{tabular}

In S4 where the mean minimum particulate was recorded, the minimum daily 8-hour monitored concentrations for day 1 and day 3 were also from there and these could be attributed to lesser haulage vehicle activities compared to the other locations. In this S4, the major activities include vehicle movement in and out of the park, engine idling, and cold start. All these activities are from the vehicles moving in or out of the park only and those in its occupation pending when there will be invitation from their process and chemical industries to move especially for loading or offloading in Lagos. While DPM is always from the haulage vehicles engines operations within the Park during movement in and out, engine idling and cold start, particulate re-suspension and particulates from break and tyre wears are additional sources from vehicle movement. However in S1 located on the median of the dual carriageway, there are higher traffic volumes when compared to S4 due to the importance of the road linking both Lagos, the commercial capital of the country to other part. In addition to the higher volume, the vehicles speeds are always reduced around this location because 
of the traffic gridlock always experienced as a result of the haulage vehicles negotiating entrance into or exit of the sub-parks within the haulage park. Though the vehicle activities in $\mathrm{S} 1$ are the same as those in S4, the higher particulate levels in S1 could be attributed to the higher traffic volumes experienced by $\mathrm{S} 1$ than $\mathrm{S} 4$.

Sampling locations S2 and S3 are sub-parks within the haulage vehicle park with varying number of vehicles. They have higher number of vehicles than that of S4 but lower than that of $S 1$. This might be responsible for the lower mean particulate concentrations in these two locations when compared to that of S1 but higher than that of S4.

The 24-hr averaging period extrapolated TSP concentrations in all the sampling locations follow the same trend in magnitude as the measured concentrations. While S4 has the minimum concentration $\mathrm{S} 1$ has the maximum.

Summarized in Table 3 are the mean meteorological parameters measured at the various sampling locations in the area during the study. These were $34.5-68.4 \%$ with an average of $52.2 \%, 28.4-$ $35.7^{\circ} \mathrm{C}$ with an average of $32.3^{\circ} \mathrm{C}$, and $0.3-1.0 \mathrm{~m} \mathrm{~s}^{-1}$ with an average of $0.8 \mathrm{~m} \mathrm{~s}^{-1}$ for relative humidity, temperature and wind speed respectively. While the fairly high temperature in the area might have aided particulate suspension from the dried unpaved floor of the park, the relative humidity could have supported retention of these particulates in the atmosphere. Though its NorthEast prevailing wind direction places the control point at the downwind of the haulage park, the observed low wind speeds could not have had strong influence on particulate concentrations - thus taking little or no particulates from the park- to the control point.

Table 3. Meteorological Parameters of the study Area during the Study

\begin{tabular}{lcccc}
\hline Level & $\begin{array}{c}\text { Temperature } \\
\left({ }^{\circ} \mathrm{C}\right)\end{array}$ & $\begin{array}{c}\text { Relative } \\
\text { Humidity } \\
(\%)\end{array}$ & $\begin{array}{c}\text { Wind Speed } \\
\left(\mathrm{m} \mathrm{s}^{-1}\right)\end{array}$ & $\begin{array}{c}\text { Wind } \\
\text { Direction }\end{array}$ \\
\hline Minimum & 28.4 & 34.5 & 0.3 & $\mathrm{NE}$ \\
\hline Maximum & 35.7 & 68.4 & 1.0 & $\mathrm{NE}$ \\
\hline Mean & 32.3 & 52.2 & 0.8 & $\mathrm{NE}$ \\
\hline
\end{tabular}

When compared with the 24-hour averaging period national ambient TSP standard in Nigeria, it was observed that the extrapolated 24-hour averaging period TSP concentration in S1 breached the standard in all the three monitored days but in S2, the standard was breached in two of the three monitored days. However in the other three locations, in none of the three days was the standard breached by the extrapolated concentrations. Averagely, this limit was breached in both S1 and S2 only. As earlier indicated the higher traffic volume coupled with heavy traffic gridlocks around S1 could be the reason for the trend observed there. Since S2 is just about $0.5 \mathrm{~km}$ from S1, these same reasons might be why there was a breach of the 24-hour averaging period national ambient particulate standard at this location. Similarly using the WHO lower $\left(150 \mu \mathrm{g} \mathrm{m}^{-3}\right)$ and upper $(230 \mu \mathrm{g}$ $\mathrm{m}^{-3}$ ) 24-hour averaging period set limits for particulates, the trend in breach of the upper limit is as in Nigeria's standard breach where the limit was breached in only sampling points S1 and S2. The lower limit was breached at sampling point S3 in addition to these two locations. However when compared with the World Bank 24-hour averaging period $80 \mathrm{\mu g} \mathrm{m}^{-3}$ limit, the extrapolated 24-hr averaging period concentrations of TSP breached this limit in all the sub-parks both by all the monitored days extrapolated concentrations and the mean concentrations. At the Control Sampling point, none of these limits was breached by the 24-hour extrapolated TSP concentrations.

As summarized in Table 4, the computed toxicity potential at the park's sampling points ranged between 0.58 and 1.92 using the Nigeria's 24-hour averaging period national ambient particulate limit but when the lower limit of the WHO was used, it was $0.97-3.20$ and $0.63-2.09$ using its upper limit. The World Bank limit gave TP ranging between 1.81 and 6.00. 
Table 4. Computed Toxicity Potential from the Measured TSP Levels during the Study

\begin{tabular}{ccccc}
\hline $\begin{array}{c}\text { Sampling } \\
\text { Location }\end{array}$ & TP $_{\text {FMENV }}$ & $\begin{array}{c}\mathrm{TP}_{\mathrm{WHO}} \\
\text { lower } \\
\text { limit }\end{array}$ & $\begin{array}{c}\mathrm{TP}_{\mathrm{WHO}} \\
\text { upper } \\
\text { limit }\end{array}$ & TP $_{\text {WorldBank }}$ \\
\hline $\mathrm{S} 1$ & 1.92 & 3.20 & 2.09 & 6.00 \\
\hline $\mathrm{S} 2$ & 1.16 & 1.94 & 1.26 & 3.63 \\
\hline $\mathrm{S} 3$ & 0.67 & 1.12 & 0.73 & 2.11 \\
\hline $\mathrm{S} 4$ & 0.58 & 0.97 & 0.63 & 1.81 \\
\hline $\mathrm{S} 5$ & 0.58 & 0.97 & 0.63 & 1.82 \\
\hline $\mathrm{Cp}$ & 0.11 & 0.18 & 0.12 & 0.33 \\
\hline
\end{tabular}

The minimum toxicity potential from all the standards considered were $0.58-1.81$ with the maximum levels of $1.92-6.00$. As the trend in the measured and 24-hour averaging period extrapolated particulate concentrations, the minimum toxicity potential was at S4 for all the regulatory standards while the maximum was at $\mathrm{S} 1$. The reason for this trend might be as earlier adduced for the measured particulate levels. At the control sampling location, the toxicity potential was $0.11-0.33$ for all the standards.

As indicated above, TP above unity poses great health challenges to the inhabitants of the airshed where such is obtained. The highest TP at S1 which is at the median of the highway on which the investigated vehicle haulage park is located calls for major concern since every commuter along the very important road will pass through this airshed. The traffic gridlock being daily experienced along this road around S1 makes it more important for adequate attention to be given to this location so as to reduce the period commuters will be exposed to this degraded air quality. Since diesel vehicle engines contribute significantly to ambient concentration of particulate pollutant (Xing et al., 2012) reduction in gridlock around this section of the road may reduce the TP. Similarly on S2 which is just about $0.5 \mathrm{~km}$ from S1, the next highest TP range in order of magnitude from all the five sampling locations occurs here. This indicates that commuters along the road in a stretch of about $1 \mathrm{~km}$ between kilometer 57 and kilometer 58 of the $3 \mathrm{~km}$ section of the highway occupied by the haulage vehicle park could be exposed to degraded air quality using particulate as indicator.

Though the TP in sampling point S3 comes next to that of S2 in order of magnitude, its TP using the Nigeria's particulate standard is less than unity. At S4 and S5, the TP becomes significant only when the World Bank limit is used in computation. Since TP at the control point were far below unity, this might confirm that the presence of the haulage vehicles and their activities around the investigated park were the reason for the elevated particulate level around this park thus establishing the danger of degraded air quality in the airshed of haulage vehicles especially with associated traffic gridlock.

Figure 2 shows the percentage contribution of each of the sampling locations to the overall TSP level of the airshed around the park. This range between $12 \%$ and $39 \%$ with sub-parks S4 and S5 the least contributors (12\%) while S1 is the highest contributor (39\%). The variations in particulate levels observed at the different sampling locations could clearly be attributed to difference in volumes of haulage vehicle activities at the park. Since S1 and S2 occupies a stretch of about 0.5 $\mathrm{km}$ of the highway on which the park is located, $62 \%$ contribution from these two locations confirms the earlier observation that traffic gridlock around this location of the highway should be minimized if not totally eliminated so as to reduce the exposure of commuters to high particulate levels on the highway.

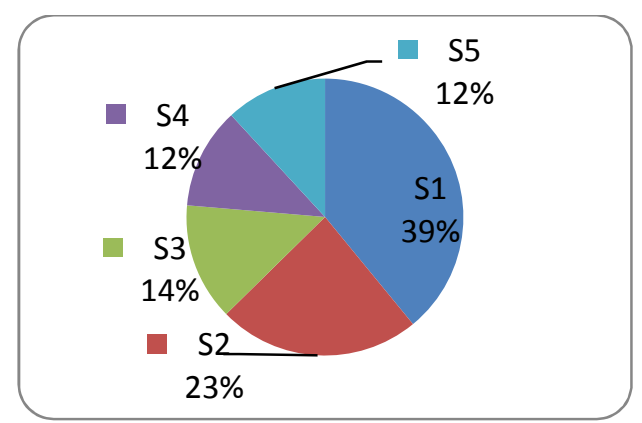

Figure 2. Percentage Contribution of Sub-Parks to the Park's TSP 


\section{CONCLUSION AND RECOMMENDATION}

The GT 331 Aerosol mass monitor was used to monitor the 8-hour averaging period total suspended particulate concentrations in the airshed of a haulage vehicle park at Ogere, Nigeria. The 24-hour TSP concentrations for the designated locations were extrapolated from the measured concentration for the purpose of assessment.

The result of the study indicated that transport-related emissions contribute significantly to the TSP level of the ambient air of the haulage vehicle park with possible health impact on humans at the host environs. The 8-hour measured TSP concentrations in the airshed ranged between 197.07 $653.28 \mu \mathrm{g} \mathrm{m}^{-3}$ with an average of $334.52 \mathrm{\mu g} \mathrm{m}^{-3}$ while its 24-hour extrapolated levels were $145.53-$ $480.29 \mu \mathrm{g} \mathrm{m}^{-3}$ with an average of $245.94 \mathrm{\mu g} \mathrm{m}^{-3}$. At the control point they were 36.23 and $26.64 \mu \mathrm{g}$ $\mathrm{m}^{-3}$ respectively. The TSP concentrations in all the designated sampling points within the haulage vehicle park breached the World Bank and WHO (lower limit) permitted limit while the FMENV TSP standard was breached at $40 \%$ of the sampling locations. The TSP concentration at the median of the dual carriageway was significant as compared to other sampling points which was attributed to the location of this point relative to the others and its high traffic volume. At the control point none of the set standards was breached.

The toxicity potential exceeding unity at some of the designated points calls for concern most especially for people in sensitive categories (young and age people as well as people with respiratory diseases). It is recommended that human activities in this area be regulated.

\section{REFERENCES}

Abbas M., Ahmadi H., Ghanbari A. and Moghaddamnia A. (2007) Dust Storms Impacts on Air Pollution and Public Health Under Hot and Dry Climate, International Journal of Energy and Environment, 2(1), 101-105.

Andreas D., Arash G., Erik S., Anders G., Mats B., Anders L., Blomqvistd G. and Mats G. (2006), Trafficgenerated Emissions of Ultrafine Particles from Pavement-tire Interface, Atmospheric Environment, 40(7), 1314-1323.

Behndig A.F., Mudway I.S., Brown J.L., Stenfors N., Helleday R. and Duggan S.T. (2006) Airway Antioxidant and Inflammatory Responses to Diesel Exhaust Exposure in Healthy Humans, European Respiratory journal, 123, 851-857.

Bashar M.A., Kamel K.A. and Khaldoun M.S. (2009). Assessment of Air Pollutants Emissions from a Cement Plant: A Case Study in Jordan, Jordan Journal of Civil Engineering, 3(3), 265 - 282.

Collings N. and Graskow B.R. (2000) Particles from Internal Combustion Engines - What We Need to Know, Philosophical Transaction of the Royal Society, 358(1775), 2611-2623.

Donaldson K., Stone V., Borm P., Jimenez L., Gilmour P., Schins R., Knaapen A., Rahman I., Faux S., Brown D. and MacNee W. (2003) Oxidative stress and calcium signaling in the adverse effects of environmental particles $\left(\mathrm{PM}_{10}\right)$, Free Radical Biological and Medicine, 34(11), 1369-1382.

Federal Environmental Protection Agency (FEPA) (1991) Guidelines to Standards for Environmental Pollution Control in Nigeria

Fridell E., Steen E. and Peterson K. (2008) Primary Particles in Ship Emissions, Atmospheric Environment, 42, 1160-1168.

Gan T.H., Hanhela P., Mazurek W. and Gillett R. (2010) Characteristics of Submarine Engine Diesel particulate in the Maritime Environment, Journal of Aerosol Science, 41, 23-35.

Gilmour P.S., Brown D.M., Lindsay T.G., Beswick P.H., MacNee W. and Donaldson K. (1996) Adverse health effects of $\mathrm{PM}_{10}$ particles: involvement of iron in generation of hydroxyl radical, Occupational and Environmental Medicine, 53, 817-822.

Guinée J. and Heijungs R.A (1993) Proposal for the Classification of Toxic Substances within the Framework of Life Cycle Assessment of Products, Chemosphere, 26, 1925-1944.

Hulskotte J.H., Van der Gon H.A., Visschedijk A.J and Schaap M. (2007) Brake Wear from Vehicles as an Important Source of Diffuse Copper Pollution, Water Sci Technol., 56(1)223-231.

Lu S., Yao Z., Chen X., Minghong W., Sheng G., Fu J and Daly P. (2008) The relationship between physicochemical characterization and the Potential Toxicity of Fine Particulates $\left(\mathrm{PM}_{2.5}\right)$ in Shanghai Atmosphere, Atmospheric Environment, 42, 7205-7214.

Met One Instruments (2001) GT-331 Operation: MODEL GT-331 Aerosol Mass Monitor Operation Manual, Met one Instruments, Inc 1600 NW Washington Blvd. Grant Pass, Oregon 97526.

Nel A. (2005) Atmosphere. Air pollution related illness; effects of particles, Science, 308(5723), 804-806. 
Nigthtingale J.A., Maggs R., Cullinan P., Donnelly L.E., Rogers D.F., Kinnersly R., Chung K.F., Barnes P.J., Ashmore M. and Newman-Taylor A. (2000) Airway Inflammation after Controlled Exposure to Diesel Exhaust Particulates, Am J Respir Crit Care med,162, 161-166.

Oberdörster G. and Utell M.J. (2002) Ultrafine Particles in the Urban Air: to the Respiratory Track and Beyond, Environmental Health Perspectives, 110, 440-441.

Owoade O.K., Olise F.S., Obioh I.B., Olaniyi H.B., Ferrero L. and Bolzacchini E. (2009) EDXRF elemental assay of airborne particulates: A case study of an iron and steel smelting industry, Lagos, Nigeria, Scientific Research and Essay, 4(11), 1342-1347.

Otto S., de Reus M., Trautmann T., Thomase A., Wendisch M. and Borrmann S. (2007) Atmospheric radiative effects of an in-situ measured Saharan dust plume and the role of large particles, Atmospheric Chemistry and Physics; 7, 4887-4903.

Pope C.A. (2000) A Review of Epidemiological Basis for Particulate Air pollution Health Standards, Aerosol Science and Technology, 30(1), 4-14.

Ramanathan V. and Carmichael G. (2008) Global and Regional Climate Changes Due to Black Carbon, Nature Geoscience, 1, 221-227.

Sacks J.D., Stanek L.W., Luben T.J., Johns D.O., Buckley B.J. and Brown J.S. (2010) Particulate matter induced health effect: Who is susceptible? Environmental health perspectives, 119, 446-454.

Sonibare J.A., Akeredolu F.A., Osibanjo O. and Latinwo I. (2005) ED-XRF Analysis of Total Suspended Particulates from Enamelware Manufacturing Industry, American Journal of applied science, 2(2), 573-578.

Thorpe J.A., Harrison R.M., Boulter P.G and McCrae I.S. (2007). Estimation of Particle Resuspension Source Strength on a Major London Road, Atmospheric Environment, 41(37), 8007-8020.

Warner L.R., Sokhi R.S., Luhana L., Boulter P.G., McCrane I. (2002), Non-Exhaust Particle Emissions from Road Transport, $11^{\text {th }}$ International Conference 'Transport and Air Pollution".

World Bank (1998) Pollution Prevention and Abatement Handbook, World Bank Group, Washington DC.

World Health Organization (WHO) (1979) Sulfur Oxides and Suspended Particulate Matter, Environmental Health Criteria 8. Geneva..

Xing W., Dane W., Jingnan H., Ye W., Hang Y., Xiaochuan P. and Zhang K.M. (2012) On-road Diesel Vehicle Emission Factors for Nitrogen Oxides and Black Carbon in two Chinese Cities, Atmospheric Environment, 46, 45-55. 